FROM SEMINARY TO UNIVERSITY

An Institutional History of the Study of

Religion in Canada 



\title{
From Seminary to University
}

An Institutional History of the Study of Religion in Canada

\author{
AARON W. HUGHES
}

UNIVERSITY OF TORONTO PRESS

Toronto Buffalo London 
(C) University of Toronto Press 2020

Toronto Buffalo London

utorontopress.com

Printed in Canada

ISBN 978-1-4875-0497-7 (cloth) ISBN 978-1-4875-3127-0 (EPUB)

ISBN 978-1-4875-3126-3 (PDF)

\section{Library and Archives Canada Cataloguing in Publication}

Title: From seminary to university : an institutional history of the study of religion in Canada / Aaron W. Hughes.

Names: Hughes, Aaron W., 1968-, author.

Description: Includes bibliographical references and index.

Identifiers: Canadiana (print) 2020018203X | Canadiana (ebook) 20200182056 | ISBN 9781487504977 (hardcover) | ISBN 9781487531270 (EPUB) | ISBN 9781487531263 (PDF)

Subjects: LCSH: Religion - Study and teaching (Higher) - Canada - History. | LCSH: Theology - Study and teaching (Higher) - Canada - History. I LCSH: Theological seminaries - Canada - History. | LCSH: Universities and colleges - Curricula - Canada - History.

Classification: LCC BL42.5.C2 H84 2020 | DDC 200.71/171 - dc23

This book has been published with the help of a grant from the Federation for the Humanities and Social Sciences, through the Awards to Scholarly Publications Program, using funds provided by the Social Sciences and Humanities Research Council of Canada.

University of Toronto Press acknowledges the financial assistance to its publishing program of the Canada Council for the Arts and the Ontario Arts Council, an agency of the Government of Ontario.

\section{Canada Council Conseil des Arts for the Arts du Canada}

Funded by the
Government of Canada
Financé par le gouvernement
du Canada

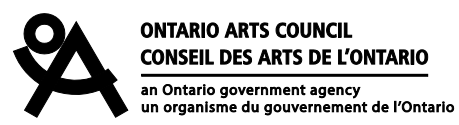

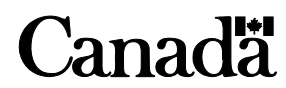

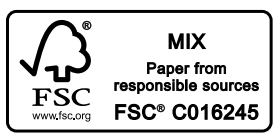


For Gabriel,

la raison avant la passion 
